\title{
Impact of Carnatic Raga-s on the Milk Yield of Cows
}

\author{
J. Sankar Ganesh \\ Assistant Professor, Department of Performing Arts \\ S.V. University, Tirupati, Andra Pradesh, India \\ (D) https://orcid.org/0000-0001-9501-9027
}

Manuscript ID:

ASH-2020-08023318

\section{Abstract}

Music is an integral part of human evolution. Indian music is religiously rooted and added as an essential part of religious activities. It is believed that Indian music originated and evolved from Samaveda. The origin of musical sounds perceived by birds and animals illustrates the close relationship of music with the environment. The other species of planet earth can also be influenced by music documented in various earlier literature. Experiments on the influence of music on the milking habit of cows started amid the 19th century in foreign countries. In India, this is a primordial attempt made by the author to study the influence of Carnatic music on the cows. This paper is intended to highlight the positive power of various aspects of Carnatic music on the milk yield of the cows. This paper is an outcome of the UGC-Major Research project, sanctioned to the author, entitled "Impact of Carnatic music on the milk yield of S.V. GosamrakshanashalaTirupati."

Year: 2020

P-ISSN: 2321-788X

Keywords: Influence of ragas, Ghana raga, Melakarta raga, Rakthi raga, Karuna rasa raga, Soka rasa raga, Mandolin, Flute, Nagaswaram, Veena, Milk yield, Peak lactation and Late Lactation Cows

E-ISSN: 2582-0397

Received: 12.06 .2020

Accepted: 27.08 .2020

Published: 01.10.2020

Citation:

Sankar Ganesh, J. "Impact of Carnatic Raga-s on the Milk Yield of Cows." Shanlax International Journal of Arts, Science and Humanites, vol. 8 , no. 2, 2020, pp. 83-87.

DOI:

https://doi.org/10.34293/ sijash.v8i2.3318

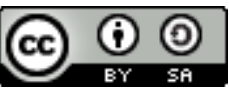

This work is licensed under a Creative Commons Attribution-ShareAlike 4.0 International License

\section{Introduction}

Trace of its origin is unknown. It could have been evolved before humans started to speak a language. Indian music is divided into two major divisions that are Hindustani music and Carnatic Music. It is believed that Indian music originated and evolved from Samaveda. Both the two Indian musical forms are spiritual and sacred.

'Music is the language of the Gods' - Prof. P.Sambamurthy.

Indian music is religiously rooted and added as an integral part of religious activities. Indian Gods are associated with musical instruments as Lord Shiva plays 'damaru' (Idukki), Nandikeswara plays Mridangam, Saraswathy Plays Veena, Lord Krishna plays flute, and sage Naradha with Tambura. Music is one of God's given gifts to humanity. Musical notes are pleasing to hear, and music can create an emotion in the listener's mind. Music is a natural art form. Musical notes originated from the sounds of animals and birds. The sound of saptaswara-s obtained from the following

1. Shadja (Sa) - Obtained from Peacock when seeing rainy clouds.

2. Rishaba (Ri) - Obtained from the lowing of cow calling its calf

3. Gandhara $(\mathrm{Ga})$ - Obtained from the bleat of the goat

4. Madhyama (Ma) - Obtained from the cry of Heron

5. Panchama $(\mathrm{Pa})$ - Obtained from the sound of Indian Nightingale

6. Dhaivatha (Dha) - Obtained from the neigh of the Horse

7. Nishada (Ni) - Obtained from the yelling of the Elephant

The origin of musical sounds from birds and animals illustrates the close relationship of music with the environment. Classical Music of India has a long testimony belong to prehistoric times. 
The supernatural power and miraculous aspects of music experimented several times in earlier history, acknowledged in various literature.

\section{Glimpses of Miraculous Effects of Music through Earlier Literature}

- From earlier Tamil literature, we realized that the mad elephant controlled by the Lute (Yaaz) music of Yazh player named Udhyanan.

- A story in Agananooru (an earlier Tamil literature) says that the elephant that came to eat the millet crop, on hearing the rendering of 'Kurinchipann' by the wife of the watcher, forgot about the feed, and gone into a deep sleep.

- In Purananuru V-291, illustrated that the women singing Vilari pan (tune) in the battlefield, near the wounded warriors, and it soothes the wound and helps them to get some sleep.

- The influence of flute music is narrated very beautifully in Bhagavatam. It says, 'The ears of the cows stand on end as they drink the nectar of this flute-song, and their calves simply stand stunned, the milk they have been drinking from their mothers' udders still in their mouths. The birds take shelter of the branches of the trees and close their eyes, listening to the song of Krishna's flute with rapt attention.'

- In Tevaram, Thirunavukarasar saved the son of Appoothiadigal; he was supposed to die because of snakebite. Thirunavukarasar saved the boy's life by rendering a thevaram 'ontru kolam avar sindai' in pan Indalam.

- Many diseases like stomach ache, cold, fever, snakebite, etc., cured through the power of music. Tevaram compositions are the authenticated earlier references for Music Therapy and its various applications.

- The agricultural yields of palm trees were fixed by Thirugnana Sambandhar, one among the Tevaram quartette by rendering a Tevaram.

\section{Ragas of Carnatic Music}

The significant feature of Carnatic music is raga. Every raga is distinctive and capable of stirring a particular kind of emotion in the mind of the listener. Technically the permutation combination of swaras, which can pleases the mind of a listener, is called raga. During the period of Carnatic Music Trinity, we have references to many miracles that have happened. The capability of a raga to control over the rain was proved by Muthuswamy Dikshithar by using the raga "Amrithavarshini." There is also information about the music therapy he exercised by using various ragas to cure his student of several severe illnesses.

\section{Music and its Impact on Cows}

Indian culture gives a special place to cows. The cow is considered as a mother; Hinduism praises cow equal to the level of Goddess Kamadhenu (Omni giver). Cows are great lovers (rasikas) of music; cow likes music, and it responds to music. There are lots of experiments practiced in international farms to increase milk yield in cows using music. Some glimpses of such attempts follow

- Psychologists at the University of Leicester, UK, attempted by playing the music of different tempos to herds of Friesian cattle and found Beethoven's Pastoral Symphony and Simon \& Garfunkel's Bridge Over Troubled Water.

- A British Colombian Dairy Association conducted a music competition for increasing milk yield in their dairy farm in 2012 in the title "Music Makes More Milk" contest. Members of the public are invited to compose songs for cows to naturally increase milk production. News wire (2012), Published on 9th Oct, - 2012.

- 'Calming music can improve milk yield, probably because it reduces stress,' said Dr. Adrian North, who carried out the study with his colleague Liam MacKenzie.

- Dr. Anna O'Brien claimed that the milk yield is increased up to $3 \%$ while playing selected music to cows.

In India, thematic research is attempted by the Author with the sponsorship of the University Grants Commission through a major research project entitled 'Impact of Carnatic music on the milk yield of S.V.Gosamrakshanashala, Tirupati.' In the above research program, systematic research was conducted to study the impact of Carnatic music on the milk yield of cows in S.V.Gosamrakshanashala, Tirupati. Caring for cows is an important aspect of Hindu dharma. Gosamrakshanashala is a place 
where all the cows are sheltered and taken care of. Sri Venkateswara Gosamrakshana shala Trust was established by Tirumala Tirupati Devasthanams (TTD) in 1956 has an approximate number of 2200 cows. It is located at the Chandragiri road, Tirupati, established with 150 acres of land.

Carnatic music manifests through multiple mediums like Vocal and instrumental. Various aspects of Carnatic music are exposed to cows and results observed. This project was conducted from 2015 to 2018, under the vigilance of a team of veterinary doctors of TTD.

Musical taste in humans shaped by several external factors like environment, social and family influence, the type of music we listen to, and internal preferences we have for rhythm, melody, timbres, arrangement, or lyrics. The inner feelings and emotions of every individual differ according to the music they hear. Like humans, cows are also great rasika-s of music. Observation shows that every cow has a taste and preference in music. Each cow's love towards music differs from others. In a group of cows, some cows like a particular type of music, and a few don't. A variation in Milk yield shows the impact of music on cows. This project work was conducted in 2 sessions, one in winter and one in summer.

\section{Results of the Study}

\section{Experiment Session 1}

1. (Dakshina Bharatha Sampradaya Bhajan) Traditional South Indian Bhajans, tuned in various ragas, influences peak lactation and late lactation cows, and the milk yield increased up to $2.13 \%$ and $2.05 \%$ during the experiment period, respectively.

2. Flute Music of Carnatic music impacts the cows, and the milk yield in peak lactation cows increased up to 0.38 liter average per day, which is $1.45 \%$ of the total milk yield. In late lactation cows, the milk yield increased to 1 liter average per day, which is a $4.97 \%$ average hike in the overall milk yield.

3. Nottuswara music has very little positive impact on peak lactation cows. The overall milk yield of the cows increased up to 0.13 liter average per day, which is $0.44 \%$ average on the overall milk yield.
4. Mandolin Music impacts the peak lactation group, and the milk yield increased up to 0.87 liter average per day, which is a $3.39 \%$ increase in the overall milk yield of the peak lactation group.

\section{Experiment Session 2}

1. Among the peak \& late lactation groups, Ghana raga-s had a positive impact. The overall milk yield increased up to 2.5 liters average per day, a $6.78 \%$ average hike and $10.86 \%$ average increase in the overall milk yield of respective groups.

2. Experiment 3 conducted with Melakartha raga-s positively influenced the peak and late lactation groups, and the overall milk yield increased up to 3.33 liters average per day in the peak lactation group, and 1.66 liters average per day in the late lactation group, which is $8.97 \%$ average increase of the overall milk yield,

3. Among the peak lactation group, the Music of Veena, experiment -4, influenced much positively. The milk yield increased up to 4.83 liters average per day, which is $14.86 \%$ of the overall milk yield of the group.

4. Rakhi raga-s (Rakhi raga's shape cannot be revealed through musical notes, and revealed only through elaborate raga alapana) has a positive impact on the milk yield of peak lactation and late lactation groups. Through experiment 5 of the second session, it is observed that the milk yield in peak and late lactation groups increased up to 4 liters average per day, and 2.33 liters average per day, which is a $12.69 \%$ and $16.64 \%$ increase of the overall milk yield of the respective groups.

5. Experiment-7 was done with karuna rasa raga-s, managed to stop the decrease of milk yield in the late lactation cows, and no change in the milk yield is observed. A drastic decrease in the milk yield of the peak lactation group was observed.

6. The Music of Nadaswaram has a positive influence on the late lactation groups, and the milk yield is increased up to 0.16 liter, which is $0.94 \%$ of the overall milk yield of the group.

\section{Conclusion}

1. Dakshina Bharatha Sampradaya bhajans that are traditional bhajans tuned in catchy raga-s, and 
set to brisk tempo, have a positive impact on the milk yield of the cows.

2. Flute music of Carnatic music, playing of melakarta raga-s, has a more positive influence on the cows, and the milk yield increased during winter.

3. Examining the overall results of a pilot study, Raga Sankarabharanam (29) and Todi (8) are the two major ragas, which are more effective and influenced the Cows of both Peak and late lactation groups. Raga Karaharapriya (22) has a little positive impact only on late lactation cows.

4. Music of string instruments like Mandolin, Veena, and Violin, playing of melakarta raga-s or other raga-s, helped in the increase of overall milk yield of both peak and late lactation cows. Most of the cows like the tonal music produced from the strings.

5. Ragas, which are capable of creating 'Soka rasa' (pathos), hurts the cows, and the milk yield decreases in both peak and late lactation cows.

6. Ghana raga-s and songs tuned in Ghana raga-s like Natta, Gowla, Arabia, Sriracha, and Varali has a positive impact on the milk yield of cows.

7. Sampoorna raga-s or Melakartha raga-s or raga-s having all the seven notes except Soka rasa raga-s like subhapanthuvarali has a positive influence on the overall milk yield of the peak and late lactation cows. (Ex: Raga-s like Sankarabharanam, Todi, Natabhairavi, Mayamalava gowla, Charukesi, Gowrimanohari, etc.

8. Rakhi raga-s like Hindolam, Mohanam, Abhi, etc, have a positive impact on the overall milk yield of the cows, and playing of these raga-s are helpful in the increase of milk yield in both peak and late lactation cows.

9. The Nagaswaram music playing sampoorna raga-s/ Melakarta raga-s or Sakthi raga-s in low volume may have a positive impact on the milk yield of the cows.

10. The temperature of the day played a vital role in the milk yield of cows. During summer, the flute music is not that much influenced the cows as in winter.

\section{Some Interesting Observations}

- The cooperation level of the cattle is increased during the milking time.

- Lazy cows became very active after listening to music.

- One cow interestingly moving its body like a dance on hearing the Pancharatna Kriti of Tyagaraja 'Entaro Mahanubhavulu' in Sri ragam set to Adi tala. This cow dance for that particular song whenever it is played in a series of songs.

\section{Acknowledgment}

1. My sincere thanks to UGC for granting me this opportunity by sanctioning the Major research project entitled 'Impact of Carnatic music on the milk yield of S.V.Gosamrakshanashala, Tirupati.'

2. My Sincere thanks to The Director, S.V. Gosamrakshanashala, Tirupati, for permitting and providing all kinds of support for this project experiment.

\section{References}

Briggs, Helen. "Sweet Music for Milking." $B B C$ News, 2001.

Chelladurai, P.T. The Splendour of South Indian Music, Vaigarai Publishers, 2000.

Dwarakanath, G. Forgotten Chapters of Music, Vasantha Vallabha Music Academy, 2012.

Ganapathyraman, N. "Music Therapy." Complementary Approach to Aspects and Applications of Music and Yoga Conference Publication, Department of Music, SRC College, Trichy, 2014, pp. 36-39.

Ganesh, J. Sankar. "Impact of Carnatic Music on Milk Yield." Shanlax International Journal of Arts, Science and Humanities, vol. 4, no. 3, 2017, pp. 55-60.

Ganesh, J. Sankar. "Miraculous Effects of the Application of Music." Complementary Approach to Aspects and Applications of Music and Yoga Conference Publication, Department of Music, SRC College, Trichy, 2014, pp. 297-299.

Godoy, Maria. "Moo-d Music: Do Cows Really Prefer Slow Jams?” npr.org, 2014. 
Menen, Rajendar. The Miracle of Music Therapy, Pustak Mahal, 2010.

"Music Tips to Increase Milk Production in News." Krishna Leela, https://www. krishnaleelagroup.com/increase-cow-milknaturally-music/

O’Bannon, Ricky. "What Does Your Music Taste Say about How You Think?" Baltimore Symphony Orchestra.

O’Brien, Anna. "Milking to Music." Modern Farmer, 2014

O’Brien, Anna. "Music to My Ears." PET MD, 2013.

"Researchers says that Cows Give more Milk when Listening to Music." Mindblowing.

Roberts, Maddy Shaw. "Classical Music Increases Cows' Milk Yield, Study Finds.” Classic FM, 2019.

"Rock On: Classical Music A Favorite Among Dairy Cows." Undeniably Dairy, 2013.

Sambamurthy, P. South Indian Music, Indian Music Publishing House, 2005.

Sankar Ganesh, J. "Impact of Carnatic Flute Music on Milk Yield." Eduventure, vol. 1, no. 1,
2018, pp. 34-38.

Schulkin, Jay, and Greta B. Raglan. "The Evolution of Music and Human Social Capability." Frontiers in Neuroscience, vol. 8, 2014.

Shankar, Vidya. The Art and Science of Carnatic Music, Music Academy, 1983.

Sharma, Manorma. Special Education: Music Therapy, APH Publishing Corporation, 2015.

Uetake, K., et al. "Effect of Music on Voluntary Approach of Dairy Cows to an Automatic Milking System." Applied Animal Behaviour Science, vol. 53, no. 3, 1997, pp. 175-182.

Vijayajaya, S. "Effects of Music Therapy." Complementary Approach to Aspects and Applications of Music and Yoga Conference Publication, Department of Music, SRC College, Trichy, 2014, pp. 251-254.

Wade, Bonnie C. Music in India: The Classical Traditions, Manohar Publishers \& Distributors, 2002.

Śrīmad-Bhāgavatam. The Gopiss Glorify the Song of Krșna's Flute, The Summum Bonum , https:// vedabase.io/en/library/sb/10/21.

\section{Author Details}

Dr. J. Sankar Ganesh, Assistant Professor, Department of Performing Arts, S.V. University, Tirupati, Andhra Pradesh, India, Email ID: jsankarganesh@gmail.com. 